\title{
INTEGRATED ASSESSMENT OF COMPETITIVE-STRATEGY SELECTION WITH AN ANALYTICAL NETWORK PROCESS
}

\author{
Yun-Huei Lee ${ }^{1}$, Yun-Huan Lee ${ }^{2}$ \\ ${ }^{1}$ Department of Business Administration, Tamkang University, Taipei, Taiwan \\ ${ }^{2}$ Finance Department, Ming Chuan University, Taipei, Taiwan \\ E-mails: ${ }^{1} y$ @@mail.tku.edu.tw; ${ }^{2}$ liyh@mail.mcu.edu.tw (corresponding author)
}

Received 20 June 2011; accepted 18 August 2011

\begin{abstract}
The present study explores efforts to identify the most appropriate competitive strategy relative to multinational biotech pharmaceutical enterprises' strategy selection. The research uses the analytic network process (ANP) technique combining both qualitative and quantitative information to construct a hierarchical model involving interactions among various criteria for competitive-strategy selection. The most important finding shows that the most suitable competitive strategy for multinational enterprises (MNEs) is differentiation strategy. The weighted calculations reveal important criteria: an external environment analysis reveals that the three most important criteria affecting FDI competitive strategy are population size, per capita income, and healthcare and medical insurance systems; a core competency analysis reveals that the three most important criteria affecting competitive-strategy selection of FDI to China are capability in collaborating with local partners, possession of high-quality research personnel with R\&D capability, and possession of a strong brand.
\end{abstract}

Keywords: competitive-strategy selection, strategy formulation, analytic network process (ANP), integrated assessment, multinational biotech pharmaceutical enterprises.

Reference to this paper should be made as follows: Lee, Y.-H.; Lee, Y.-H. 2012. Integrated assessment of competitive-strategy selection with an analytical network process, Journal of Business Economics and Management 13(5): 801-831.

JEL Classification: C63, F23, M00.

\section{Introduction}

Since implementing an open-door policy in 1978, China has witnessed dramatic growth in the large amounts of inflow of foreign direct investment (FDI) into China. China has replaced the United States, becoming the largest recipient of FDI in 2003. China has successfully attracted FDI from multinational enterprises (MNEs), and MNEs of the biotech pharmaceutical industry are not excluded.

The biotech pharmaceutical industry has enormous opportunities to grow. Along with the technology development in the pharmaceutical field, nowadays the importance of biotech pharmaceutical products is greater than ever and increasing (Business Wire, 2009). In China, the biotech pharmaceutical industry has been growing rapidly. It has 
been expanding at about $25 \%$ annually for the past few years and is poised for further expansion (Zhou 2007). According to research reports in China Research and Intelligence (2008), in 2008 the market size of China's biotech pharmaceutical industry was about 70 billion Yuan (about US $\$ 10$ billion), a growth rate exceeding the whole market size of China's medicine market and also above three sub-sectors: chemical medicine materials, chemical medicine doses, and traditional Chinese prepared medicines. Under the current global economic recession, however, the development of China's biotech pharmaceutical industry has exhibited impressive momentum. The gradual expansion of China's biotech pharmaceutical industry is due to such favorable factors as China's rapid economic growth, people's growing incomes, increased understanding of and demand for biotech pharmaceutical medicine, improvements in China's healthcare system, and people's rising awareness of disease treatment. Fig. 1 shows the market scale of the biotech pharmaceutical industry in China during the period stretching from 2003 to 2007 (China Research and Intelligence 2008).

Facing uncertainties and ambiguities prevalent in the Chinese business environment, more and more MNEs are turning to a strategic approach as the way forward. How MNEs choose an appropriate market-entry strategy has become an important issue. An accurate competitive strategy has positive effects on business performance (Kirca et al. 2005; Matsuno, Mentzer 2000; Olson et al. 2005; Strandskov 2006; Vorhies, Morgan 2003). Studies about the relations between strategy and competitive advantage are discussed from two different perspectives. Competitive strategy is concerned with creating and maintaining a competitive advantage in each and every area of business (Thenmozhi 2011). Using a competitive strategy, an enterprise can position itself within an industry in such a way as to take best advantage of the competitive forces active in the industry. One approach of existing studies is to identify the key success factors (KSFs) of an industry on the basis of traditional theory, which emphasizes industrial organization. Other studies empirically identify the capabilities and the resources from the viewpoint of competence theory. Since KSFs change according to the industry in question, the possibilities of intervention depend on technology variables and on socialeconomic variables. Competitive advantage may not be sustainable in a changing or

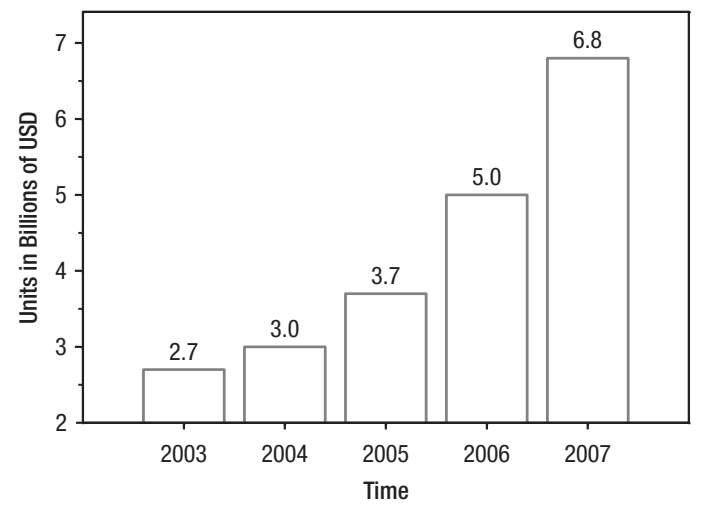

Fig. 1. Market Scale of Biotech Pharmaceutical Industry in China (2003-2007) 
changed set of environmental conditions. Also, resources are not always linked to a core competence. Capabilities are termed 'core' when they result in a competitive advantage over other firms. This implies (1) that previous studies did not sufficiently address the factor of resources and (2) that capability, when transformed into core competency, can become competitive strength (De Saa-Perez, Garcia-Falcon 2002; Ginevičius et al. 2010; Korsakiene 2004).

Previous research targeting market-entry strategies, especially in the context of the biotech pharmaceutical industry, has focused on corporate-level strategy resulting in entities and events such as joint ventures, strategic alliances, mergers and acquisitions, and licensing agreements (Brouthers 2002; Chen, Lou 2004; Deeds, Hill 1996; Richards, DeCarolis 2003; Shan, Song 1997). To our knowledge, no study focuses on competitive (business)-level strategy, which is the foundation of successful business. For a firm trying to establish itself internationally, choosing a strategy for entry into a foreign market is of crucial importance. Therefore, to fill the gap in the literature, the current study elaborates on how multinational biotech pharmaceutical enterprises that are willing to invest in, or are currently investing in and want to expand, their business select an appropriate competitive strategy to compete in China. We use analytic network process (ANP) to construct a hierarchical model involving interactions among various factors for competitive-strategy selection: rests on integrated assessment including external factors and internal factors. The findings not only identify important factors of FDI for competitive strategy and rank them according to their importance, but also rank competitive strategies according to their level of competitiveness for decision makers.

The remainder of this paper is structured as follows. The second section presents a comprehensive review of the literature covering competitive (business) strategy, strategy formulation, and the ANP approach. The third section describes the current study's research process and research methodology as applied in this research. The empirical analysis and findings are discussed in Section 4. Section 5 concludes this paper and provides managerial implications.

\section{Literature review}

This section presents a review of related literature in three parts: competitive (business) strategy, strategy formulation, the ANP approach and summary.

\subsection{Competitive (business) strategy}

In the world of business, strategy is a way by which a firm fulfills its mission and attains its objectives. Brandenburger and Stuart (1996) mentioned that the essence of strategy lies in creating favorable asymmetries between a firm and its rivals. A good strategy neutralizes threats, exploits opportunities, capitalizes on strengths, and fixes weaknesses. The hierarchical view of strategy visualizes at least three levels of strategies. First, within large multi-business corporations, corporate strategy involves the selection of product markets or industries and the allocation of resources among them. Corporate-strategy decisions include investment in diversification, vertical integration, acquisitions, and new ventures. Second, business strategy is concerned with how the 
firm competes within a particular industry or market. Porter referred to a business strategy as a competitive strategy. Pearce and Robinson (2003) indicated that competitive strategy strives to identify and secure the most prominent market segment within such a product-market arena. Thus, competitive strategies determine how the enterprise (business unit) must compete within such a segment in order to establish a competitive advantage. Each business unit within a multi-business firm could have its own specially tailored competitive strategy designed to strengthen the individual business units' use of distinctive competencies as competitive weapons. Third, functional strategies are the elaboration and implementation of business strategies through individual functions such as production, R\&D, marketing, human resources, and finance. They are primarily the responsibility of the functional departments (Bernard 2010; Swamidass, Newell 1987).

Several strategic typologies have been proposed in the strategic-management literature over the years (Barczak 1995; Chrisman et al. 1988; Miles, Snow 1978; Porter 1980). Barczak (1995) suggested three strategic types based on the timing of entry, the first-tomarket scenario, the fast-follower scenario, and the delayed-entrant scenario. Miles and Snow (1978) postulated four strategic types: defenders, prospectors, analyzers, and reactors. Porter (1980) described a typology consisting of three general types of strategies (cost leadership, differentiation, and focus) that businesses commonly use to achieve and maintain competitive advantage. These strategies are applied at the business-unit level, and they are not firm or industry dependent. Product differentiation fulfills a unique customer need by tailoring the product or service, allowing organizations to charge a premium price to capture market share. The differentiation strategy is implemented effectively when the business provides unique or superior value to the customer through product quality, features, or after-sale support. Firms following a differentiation strategy can charge a higher price for their products on the basis of product characteristics, delivery system, quality of service, or distribution channels. Spanos and Lioukas (2001) argued that there are at least two types of differentiation strategies. One is based on innovation differentiation, whose function is to make possible the most advanced and attractive products regarding the novelty of their quality, efficiency, design, or style. The other is based on marketing differentiation, whose function is to create a unique image for a product through marketing practices. Lower costs and cost advantages result from process innovations, learning-curve benefits, economies of scale, reductions, product designs that reduce manufacturing time and costs, and reengineering activities. Low-cost leadership strategy requires a vigorous pursuit of cost reductions deriving from experience, tight cost and overhead controls, avoidance of managerial customer accounts, and cost minimization in all activities, such R\&D, advertising, process innovation, and product development. This strategy is implemented effectively when the firm designs, produces, and markets a product more efficiently than competitors. The focus is also known as a "niche" strategy, wherein the firm concentrates on a narrow competitive scope within the industry. Firms that succeed in a "focus strategy" are able to tailor a broad range of product-development strengths to a relatively narrow market segment that they know very well. Focus strategies grow market share by operating in a niche market or markets not attractive to, or overlooked by, larger competitors. A 
successful focus strategy needs an industry segment large enough to have good growth potential but not of key importance to major competitors. Firms may use a focus strategy in conjunction with either the cost or differentiation strategies in a specific market niche (Allen et al. 1999).

\subsection{Strategy formulation}

Strategy formulation is the process of deciding the best course of action for accomplishing organizational objectives (Management Study Guide 2011; Karnitis, Kucinskis 2009). To formulate effective strategies, managers in an organization need to be aware of realities in a given business environment. Strategy formulation thus begins with a scanning of the external as well as internal environment. Analysis of an external environment helps to identify the possible threats and opportunities while analysis of an internal environment helps to identify strengths, weaknesses, and the key people within the organization being analyzed. An organization requires an analysis of what is happening outside the organization and an evaluation of current resources and an assessment of opportunities and threats present in the environment. Environment could be classified as external and internal (Thenmozhi 2011). Internal variables (in the firm) and external variables (in the industry) largely determine what type of competitive strategy a firm will choose to follow. O'Regan and Ghobadian (2004) pointed out that external and internal characteristics are the key factors considered in developing strategy. Toni and Tonchia (2003) considered strategy a long-term plan and noted that business is not conducted within a fixed environment. These strategic internal variables and external variables, which drive competitive strategy, change continuously. Competitive strategy may therefore adapt to changing circumstances in order to better position the enterprise seeking to benefit from the strategy. The above researchers argued that it is essential to integrate a twofold viewpoint: external and internal views.

The external environment consists of variables that are outside the organization and not typically within the short-run control of top management. The general factors, called the overall societal environment, comprises socio-cultural, economic, technological, political, and legal forces; and specific factors, called the task environment, include suppliers, employers, competitors, trade associations, communities, creditors, customers, specialinterest groups, government, and shareholders. In order to have a better understanding of an industry's external environment, one must analyze the industry itself in detail. Usually competition analysis proceeds along with industry analysis. Ginter et al. (1992) proposed that macro environmental analysis is strategic thinking in strategic planning. Macro environments can be seen from five different perspectives: demographic, technological, political-legal, economic, and socio-cultural perspectives. The five different perspectives of macro environmental analysis are also mentioned by Hitt et al. (2007). The method widely used is Porter's Five-forces Model: barriers to entry, bargaining power of suppliers, bargaining power of buyers, rivalry among existing players, and threat of substitute products (Thenmozhi 2011). Pan (1999) proposed a simplified framework that encompassed two main elements for pharmaceutical companies' strategic launch decisions relevant to a new product: an external analysis (targeting customers, competitors, 
the market, and the environment in which the new product would compete), and an internal/self analysis of the company (the company's overall performance and strategic options) (Trim, Pan 2005).

The resource-based perspective rests on an internal analysis of firms and suggests that firms are a collection of heterogeneous resources (tangible and intangible) that are semi-permanently tied to a company (Wernerfelt 1984). The study of the corecompetency concept for strategy formulation has generated enormous interest since it is an element of successful strategy for MNEs (Grant 1991; Hoskisson et al. 2004; Kak 2004; O’Tegan, Ghobadian 2004; Prahalad, Hamel 1990; Toni, Tonchia 2003). Core competency is a concept well known to academics, business practitioners, and consultants in strategic management. Scholars have acknowledged the importance of core competency in formulating strategy (Grant 1991; Lahti 1999; Toni, Tonchia 2003; O'Tegan, Ghobadian, 2004). Bogner et al. (1996) analyzed the 41 largest pharmaceutical firms in the United States and Western Europe in terms of their core competencies and looked at how the relative competitive postures of these firms changed in the US market between 1969 and 1988. Kak (2004) explored a case study of two pharmaceutical organizations to investigate the issues related to core-competency development and strategy formulation with core competency. The findings revealed that the core competencies in Eli Lilly \& Company, a worldwide leader in pharmaceuticals, were R\&D and marketing, whereas the core competencies of another global pharmaceutical company, Pharmacia \& Upjohn, were R\&D and dedicated manpower. Another study narrowed its focus on biotech pharmaceuticals and emphasized the future importance of R\&D leadership for this industry (Feltz 2007). Powell et al. (1992) suggested that firms in a wide range of industries were executing nearly every step in the production process through some form of external collaboration. These researchers argued that biotechnology firms were opting to sustain - by means of vertical integration - their competitive ability to learn through interdependence rather than through independence. With the growing complexity of process development, R\&D firms like Pfizer have come to realize that they need to collaborate with other organizations that have expertise (Mehta, Peters 2007). Liu and Cheng (2000) pointed out that the entry strategies in China for pharmaceuticals may involve more complicated considerations: government policies (including legislation, healthcare insurance, medical insurance, regulatory affairs, and distribution), brand position, corporate strategies (consisting of target segments, marketing, spending, market channels, and prices), product life cycle, order of entry, and product category.

\subsection{Analytic network process (ANP)}

The analytic hierarchy process (AHP) is a powerful tool for dealing with complex multi-criteria decision-making problems, and can help to establish decision models that account for both qualitative and quantitative components. The AHP helps analysts to organize the critical aspects of a problem into a hierarchy rather into a family tree (Bevilacqua et al. 2004). By reducing complex decisions to a series of simple comparisons and rankings, and by then synthesizing the results, the AHP not only helps the analysts 
to arrive at the best decision, but also provides a clear rationale for the choices made (Chin et al. 1999). Since the AHP was first proposed by Saaty (1980), it has been applied in a variety of fields. The AHP represents a framework with unidirectional relationships among elements of the system, which implies that lower levels do not affect upper levels. A hierarchical model therefore is not appropriate for a complex system involving interaction among various factors. The development of the analytic network process (ANP) emerged to fill this gap.

The ANP - also introduced by Saaty (1996) - is the generic form of the AHP. The ANP does not require hierarchical structure, because it replaces the hierarchy in the AHP with a network incorporating feedback and interdependent relationships among elements. Not only does the importance of the criteria determine the importance of the alternatives as in a hierarchy, but also the importance of the alternatives may affect the importance of the criteria (Saaty 1996, 2006). The ANP provides a general framework for dealing with decisions without generating assumptions about the independence between levels of a hierarchy (Saaty 2005).

In general, the decision framework described by a network in ANP can be drawn graphically. In the ANP approach, the interdependence occurring among attributes and attribute levels is represented by two-way arrows (or arcs). Interdependency relationships that occur within the same level of analysis are represented by looped arcs. The directions of the arcs signify dependence, arcs emanate from an attribute to other attributes that may influence it (Meade, Sarkis 1999).

The process of ANP proceeds according to the following four steps (Chung et al. 2005; Lin et al. 2009):

(1) Model construction and problem structuring

The problem should be stated clearly and decomposed into a rational system like a network. Decision-makers can identify or develop a structure by brainstorming or by undertaking other appropriate methods (Yüksel, Dagdeviren 2007).

(2) Pairwise comparison matrices and priority vectors

In ANP, like AHP, decision elements at each cluster are compared pairwise with respect to their importance for their control criterion, and the clusters themselves are also compared pairwise with respect to their contribution to a goal. Interdependencies among elements of a cluster must also be examined pairwise; the influence of each element on other elements can be represented by an eigenvector (Yüksel, Dagdeviren 2007). The relative importance values are determined with Saaty's (1980) nine-point scale. A score of 1 represents equal importance between the two elements and a score of 9 indicates the extreme importance of one element (row cluster in the matrix) compared to another one (a column of clusters in the matrix) (Meade, Sarkis 1999). A reciprocal value is assigned to the inverse comparison; that is, $a_{i j}=$ $1 / a_{j i}$, where $a_{i j}\left(a_{j i}\right)$ denotes the importance of the $i$ th $(j$ th) element in the matrix of pariwise comparison $A$. Like AHP, pairwise comparison in ANP is made in the framework of a matrix, and a local priority vector can be derived as an estimate of 
relative importance associated with the elements (or clusters) being compared. The derivation can be solved on the basis of the following equation

$$
A \times w=\lambda_{\max } \times w,
$$

where $A$ is the matrix of pairwise comparison, $w$ is the eigenvector with respect to $\lambda_{\max }$, and $\lambda_{\max }$ is the largest eigenvalue of $A$ (Yüksel, Dagdeviren 2007). Saaty (1980) proposes several algorithms to approximate $w$. In this paper, we use the computer software Expert Choice to compute the eigenvectors from the pairwise comparison matrices and to determine the consistency ratios.

(3) Supermatrix formation

The supermatrix concept is similar to the Markov chain process (Saaty 1996). To obtain global priorities in a system with interdependent influences, the local priority vectors are entered in the appropriate columns of a matrix. As a result, a supermatrix is actually a partitioned matrix, where each matrix segment represents a relationship between two nodes (components or clusters) in a system (Meade, Sarkis 1999). Let the components of a decision system be $\mathrm{C}_{k}, k=1,2, \ldots, n$. Each $\mathrm{C}_{k}$ contains $m k$ elements denoted as $e_{k 1} \cdots e_{k m k}$. The local priority vectors obtained in Step 2 are grouped and located in appropriate positions in a supermatrix according to the flow of influence from a component to another component, or from a component to itself as in the loop. A standard form of supermatrix is shown in expression (2) (Saaty 1996).

$$
\begin{aligned}
& \begin{array}{lll}
\mathrm{C}_{1} & \mathrm{C}_{k} & \mathrm{C}_{n}
\end{array} \\
& e_{11} \cdots e_{1 m 1} \cdots e_{k 1} \cdots e_{k m k} \cdots e_{n 1} \cdots e_{n m n} \\
& e_{11} \\
& \mathrm{C}_{1} \quad \text { : } \\
& \begin{array}{cc} 
& \begin{array}{c}
e_{1 m 1} \\
\vdots
\end{array} \\
& \vdots \\
& e_{k 1} \\
& \vdots \\
& e_{k m k} \\
\vdots & \vdots
\end{array} \quad\left[\begin{array}{ccccl}
w_{11} & \cdots & w_{1 k} & \cdots & w_{1 n} \\
\vdots & \vdots & \vdots & \vdots & \vdots \\
w_{k 1} & \cdots & w_{k k} & \cdots & w_{k n} \\
\vdots & \vdots & \vdots & \vdots & \vdots \\
w_{n 1} & \cdots & w_{n k} & \cdots & w_{n n}
\end{array}\right] . \\
& \begin{array}{cc} 
& e_{n 1} \\
\mathrm{C}_{n} \quad & \vdots \\
& e_{n m n}
\end{array}
\end{aligned}
$$

As an example, the supermatrix $W$ representation of a hierarchy with three levels as shown in Fig. 2(A) is as follows (Saaty 1996)

$$
W_{h}=\left[\begin{array}{ccc}
0 & 0 & 0 \\
W_{21} & 0 & 0 \\
0 & W_{32} & I
\end{array}\right] .
$$


In this matrix, $w_{21}$ is a vector that represents the impact of the goal on the criteria, $W_{32}$ is a matrix that represents the impact of criteria on each of the alternatives, $I$ is the identity matrix, and entries of zeros correspond to elements that have no influence.

For the above example, if the criteria are interrelated among themselves, the hierarchy is replaced by a network as shown in Fig. 2(B). The $(2,2)$ entry of $W_{n}$ given by $W_{22}$ would indicate the interdependence, and the supermatrix would be as follows (Saaty 1996):

$$
W_{n}=\left[\begin{array}{ccc}
0 & 0 & 0 \\
W_{21} & W_{22} & 0 \\
0 & W_{32} & I
\end{array}\right] .
$$

Note that any zero in the supermatrix can be replaced by a matrix if there is an interrelationship of the elements in a component or between two components. Since there usually is interdependence among clusters in a network, the columns of a supermatrix usually yield a sum of more than one. The supermatrix must be transformed first to make it stochastic, that is, each column of the matrix sums to unity. A recommended approach by Saaty (1996) is to determine the relative importance of the clusters in the supermatrix, with the column cluster (block) as the controlling component (Meade, Sarkis 1999). That is, the row components with non-zero entries for their blocks in that column block are compared according to their impact on the component of that column block (Saaty 1996). To obtain an eigenvector, one can conduct a pair-wise comparison matrix of the row components with respect to the column component. This process gives rise to an eigenvector for each column block. For each column block, the first entry of the respective eigenvector is multiplied by all the elements in the first block of that column, the second by all the elements in the second block of that column, and so on. In this way, the block in each column of the supermatrix is weighted, and the result is known as the weighted supermatrix, which is stochastic.

Raising a matrix to powers gives the long-term relative influences of the elements on each other. To achieve a convergence on the importance weights, the weighted supermatrix is raised to the power of $2 k+1$, where $k$ is an arbitrarily large number,
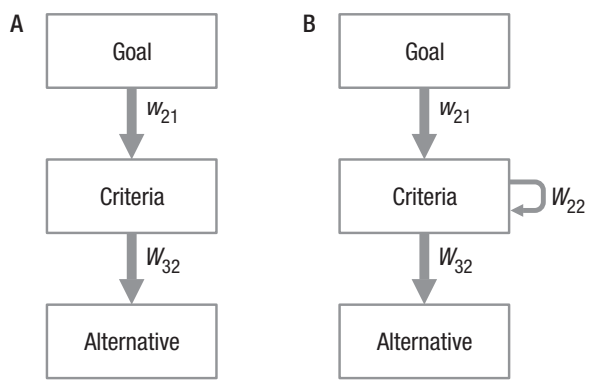

Fig. 2. Hierarchy and network: (A) hierarchy; (B) network 
and this new matrix is called the limit supermatrix (Saaty 1996). The limit supermatrix has the same form as the weighted supermatrix, but all the columns of the limit supermatrix are the same. By normalizing each block of this supermatrix, the final priorities of all the elements in the matrix can be obtained.

(4) Selection of the best alternatives

The selection of the best alternative depends on the normalized supermatrix. which overall priority weights of the alternatives are shown in it. On the other hand, if a supermatrix comprises only components that are interrelated, additional calculations are necessary to obtain the overall priorities of the alternatives. The alternative with the largest overall priority should be the one selected.

\subsection{ANP literature}

ANP can act as a valuable method for solving many multi-purpose, complicated decision-making problems. Over the years, there have been many ANP methods applied by various authors. Chung et al. (2005) developed a model for the selection of product mix with an ANP application. In Lee and Kim's (2000, 2001) studies, they used ANP for interdependent information-system project selection to find project priorities. In two studies by Meade and Sarkis (1998, 1999), ANP served to identify appropriate logistic strategies and to improve production speed. Momoh and Zhu (2003) used ANP to illustrate optimal production schedules. Partovi (2006) presented a strategic solution to the facility-location problem, and the solution uses ANP to incorporate both external and internal criteria in the decision-making process. Sarkis (2002) presented a framework that, based on ANP, effectively treats tangible, intangible, strategic, and operational factors in the strategic evaluation of suppliers. Tesfamariam and Lindberg (2005) proposed an application of ANP in selecting the best among competing system configurations. Ulutas (2005) specified an appropriate energy policy for Turkey. Wua and Lee (2007) selected knowledge-management strategies using the ANP method. Yurdakul (2003) constructed a model by using the ANP technique to evaluate long-term performances of production systems.

\subsection{Summary}

Strategy research examines mainly why firms differ in overall performance and achieve sustainable competitive advantage over other firms. Briefly, the research seeks to establish why some firms are more successful than others. The prior literature addressed this important question by suggesting the need to achieve a fit or balance between the firm's internal environment and its external-operating environment (Volberda 1996). A proper scanning of internal and external environments helps to identify strategic alternatives that harness strengths and overcome weaknesses in the light of opportunities and threats operating in the environment (Ghazinoory et al. 2011; Thenmozhi 2011). In this research, we focus on (1) macro-level environmental analysis and industry analysis as the external environmental analysis and (2) core-competencies analysis as the internal environmental analysis. We held a focus-group discussion (FGD) with eight experts (see Appendix 1) to determine-following the aforementioned literature and the characteristics of the biotech pharmaceutical industry-preliminary macro-level environmental fac- 
tors, industry factors, and core competencies that influence China-based multinational biotech pharmaceutical enterprises' strategy selection relative to FDI. The preliminary comprehensive factors involve international-strategy decisions. But not all determinants are relevant for each enterprise; there may be only a few important factors, and they would dominate the decision-making processes in each business (Stevenson 1996). The current study also accounts for Porter's (1980) approach to generating preliminary business strategies because his typology is similar to others' and has received more empirical support from previous research than other typologies. In addition, the object herein is to select the best competitive strategy from alternatives for biotech pharmaceutical firms. The problem becomes complex owing to numerous criteria that have interactions between each other and within themselves. It is not easy to analyze most criteria and their various levels correctly. Therefore, it is necessary to harness a technique combining both qualitative and quantitative information. It seems appropriate to use ANP as an analytic tool for strategy selection because of its suitability in providing solutions in such a complex multi-criteria decision environment.

\section{Research process and proposed model implementation}

The research process of this study is divided into five steps, as presented in Fig. 3, and these steps are described in the following section. The model for competitive-strategy selection is proposed in Fig. 4. This framework is divided into five levels. The first level is the framework goal. Dimensions for assessing an environment are listed in the second level; each dimension has several detailed groups that are listed in the third level. And each group includes more criteria that are on the fourth level. The fifth level consists of three alternatives. Appendix 2 presents the corresponding detailed definitions. The hierarchical model depicts a situation where there is no interaction among the dimensions and groups, while the loop diagram indicates a situation where there is interaction between criteria. Fig. 5 shows the network with representative symbols.

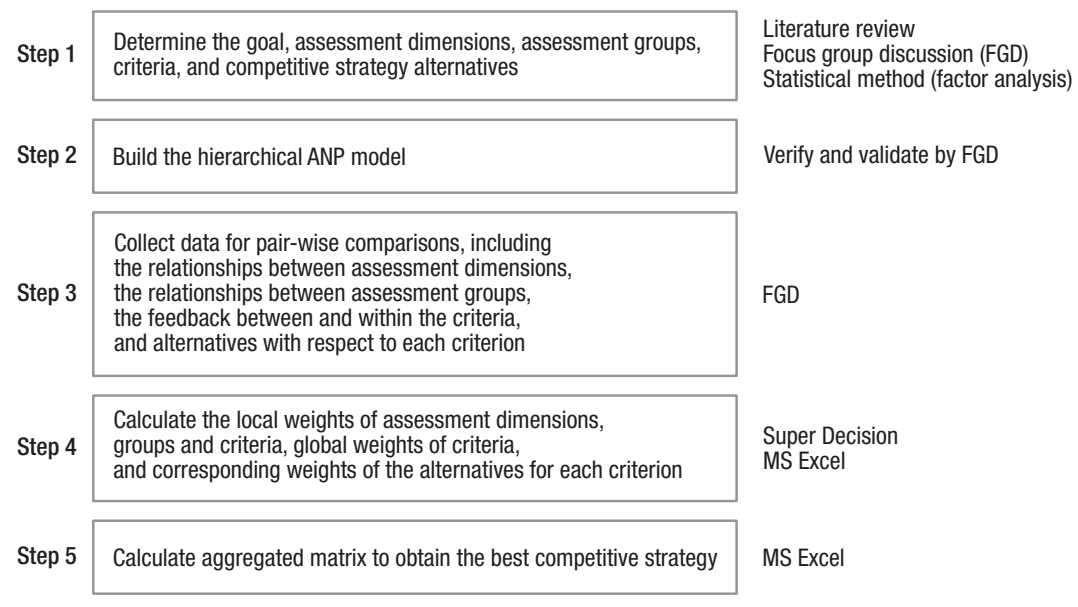

Fig. 3. The proposed research process for selecting the best competitive strategy alternative 


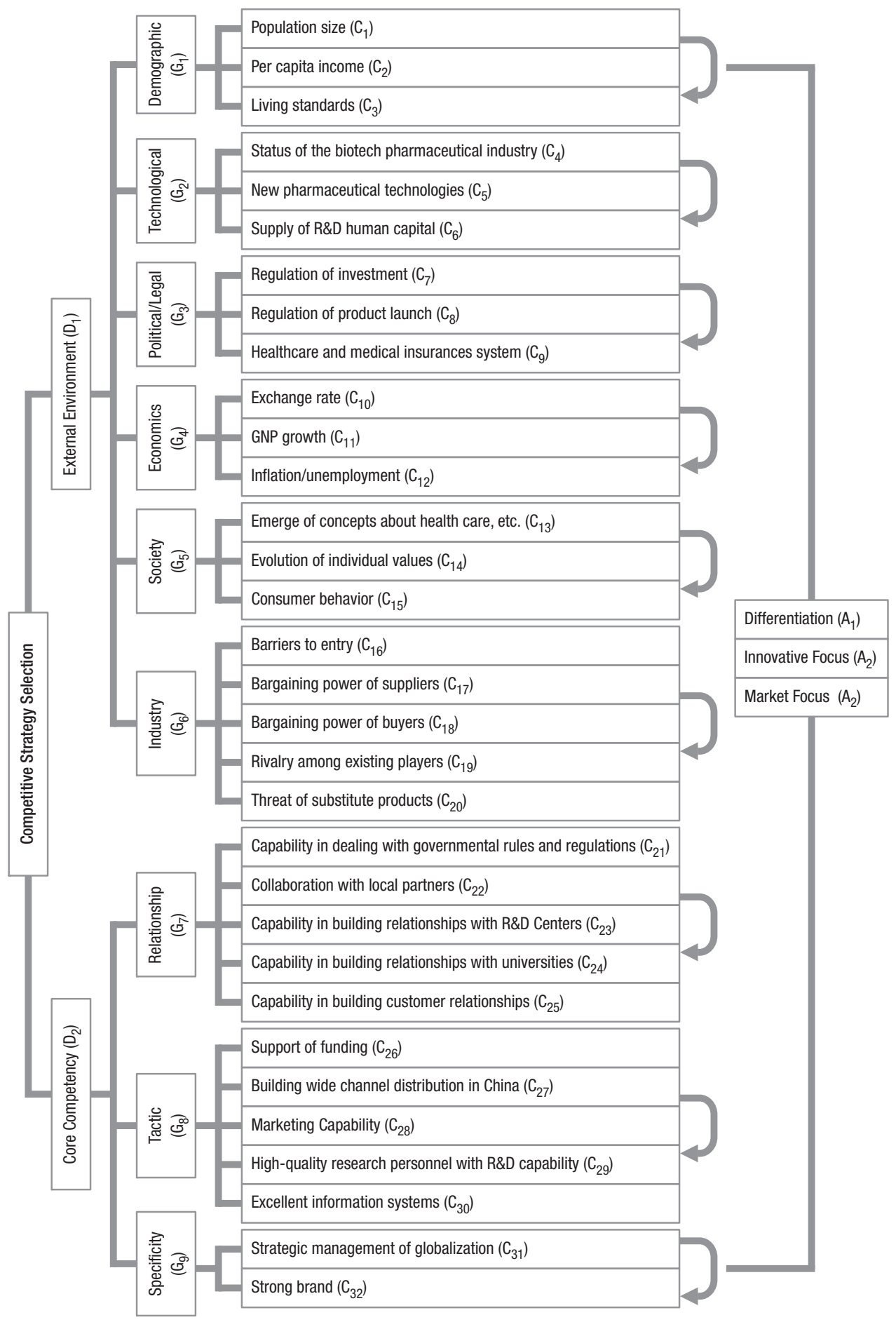

Fig. 4. The ANP model for competitive-strategy selection 


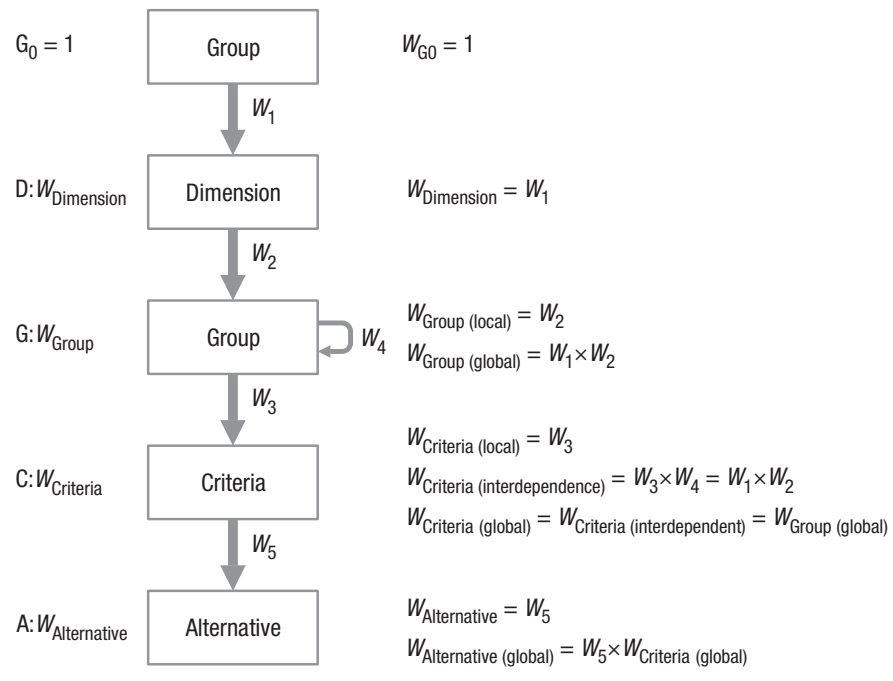

Fig. 5. The network with symbols

\subsection{Calculating the weights of assessment dimensions with respect to the goal}

In this step, two assessment dimensions are compared to each other with respect to goal. The pair-wise comparisons rest on FGD and on geometric mean rule; then pairwise comparison matrices are formed with a 1-9 scale. The scale regarding relative importance to measure the relative weights can be seen in Table 1. With values, the eigenvector is obtained by using Expert Choice software as shown in Table 2 (calculate $\left.W_{\text {Dimension }}=W_{1}\right)$.

\subsection{Calculating the weights of assessment groups with respect to the dimension}

First, comparing the groups, for example Macro and Technological are compared using the question "How important is Macro when it is compared with Technological?" we get the following data (Table 3). Then the global weight matrix for each group is obtained by multiplying with each corresponding $W_{\text {Dimension }}$ as shown in Table 4 (calculate $W_{\text {Group(global)n }}=W_{\text {Dimension }} \times W_{\text {Group(local) }}=W_{1} \times W_{2}$ ).

\subsection{Calculating the global weights of each criteria}

It is not possible to assume criteria to be independent. Therefore, we analyze the impact of each criterion on all other criteria by using pairwise comparisons. First, criteria's local weights in each assessment group are determined in the same way. Table 5 present the respective weights of the 32 criteria with respect to assessment groups. Next, the FGD serve to identify the inner loops among the criteria in each group. There are relations between the criteria in all groups except the socio political group. Eight pairwise comparison matrices were formed for 29 criteria. The resulting relative importance weights of these dependence matrixes were calculated listed in Table 6 to Table 13, separately for each criterion. 
Table 1. Linguistic scales for the importance weight

\begin{tabular}{|c|c|c|}
\hline $\begin{array}{l}\text { Linguistic } \\
\text { scales for } \\
\text { importance } \\
\text { degree }\end{array}$ & Linguistic terms & Explanation \\
\hline 1 & Equal Importance & $\begin{array}{l}\text { Two activities contribute equally to the } \\
\text { objective }\end{array}$ \\
\hline 3 & Moderate importance & $\begin{array}{l}\text { Experience and judgment slightly favor } \\
\text { one activity over another }\end{array}$ \\
\hline 5 & Strong importance & $\begin{array}{l}\text { Experience and judgment strongly favor } \\
\text { one activity over another }\end{array}$ \\
\hline 7 & $\begin{array}{l}\text { Very strong or demonstrated } \\
\text { importance }\end{array}$ & $\begin{array}{l}\text { An activity is favored very strongly over } \\
\text { another; its dominance demonstrated in practice }\end{array}$ \\
\hline 9 & Extreme importance & $\begin{array}{l}\text { The evidence favoring one activity over another } \\
\text { is of the highest possible order of affirmation }\end{array}$ \\
\hline $2,4,6,8$ & $\begin{array}{l}\text { For compromise between the } \\
\text { above values }\end{array}$ & $\begin{array}{l}\text { Sometimes one needs to interpolate a } \\
\text { compromise judgment numerically because } \\
\text { there is no good word to describe it }\end{array}$ \\
\hline $\begin{array}{l}\text { Reciprocals } \\
\text { of above }\end{array}$ & $\begin{array}{l}\text { If activity } i \text { has one of the } \\
\text { above nonzero numbers } \\
\text { assigned to it when compared } \\
\text { with activity } j \text {, then } j \text { has } \\
\text { the reciprocal value when } \\
\text { compared with } i\end{array}$ & $\begin{array}{l}\text { A comparison mandated by choosing the } \\
\text { smaller element as the unit to estimate the } \\
\text { larger one as a multiple of that unit }\end{array}$ \\
\hline
\end{tabular}

Table 2. Pair-wise comparison matrix and weights of assessment dimensions

\begin{tabular}{cccc}
\hline Dimensions & $\mathrm{D}_{1}$ & $\mathrm{D}_{2}$ & $W_{\text {Dimension }}$ \\
\hline $\mathrm{D}_{1}$ & 1 & 0.23 & 0.219 \\
$\mathrm{D}_{2}$ & 4.29 & 1 & 0.781 \\
\hline
\end{tabular}

Table 3. Pair-wise comparison matrix and weights under each assessment group

\begin{tabular}{cccccccc}
\hline $\mathrm{D}_{1}$ & $\mathrm{G}_{1}$ & $\mathrm{G}_{2}$ & $\mathrm{G}_{3}$ & $\mathrm{G}_{4}$ & $\mathrm{G}_{5}$ & $\mathrm{G}_{6}$ & $W_{\text {Group(local) }}$ \\
\hline $\mathrm{G}_{1}$ & 1 & 0.910 & 0.435 & 1.248 & 0.726 & 1.732 & 0.231 \\
$\mathrm{G}_{2}$ & 1.099 & 1 & 1.154 & 1.232 & 2.069 & 1.732 & 0.201 \\
$\mathrm{G}_{3}$ & 2.298 & 0.866 & 1 & 1.277 & 2.568 & 2.236 & 0.193 \\
$\mathrm{G}_{4}$ & 0.801 & 0.812 & 0.783 & 1 & 1.383 & 1.732 & 0.161 \\
$\mathrm{G}_{5}$ & 1.378 & 0.483 & 0.389 & 0.723 & 1 & 1 & 0.119 \\
$\mathrm{G}_{6}$ & 0.577 & 0.577 & 0.447 & 0.577 & 0.577 & 1 & 0.104 \\
\hline $\mathrm{D}_{2}$ & $\mathrm{G}_{7}$ & $\mathrm{G}_{8}$ & $\mathrm{G}_{9}$ & & & & $W_{\text {Group(local) }}$ \\
\hline $\mathrm{G}_{7}$ & 1 & 0.616 & 2.282 & & & & 0.343 \\
$\mathrm{G}_{8}$ & 1.623 & 1 & 2.404 & & & & 0.483 \\
$\mathrm{G}_{9}$ & 0.438 & 0.416 & 1 & & & & 0.174 \\
\hline
\end{tabular}


Table 4. The global weight for each group

\begin{tabular}{cccc}
\hline $\mathrm{D}_{1}$ & $W_{\text {Group(local) }}$ & $W_{\text {Dimension }}$ & $W_{\text {Group(global) }}$ \\
\hline $\mathrm{G}_{1}$ & 0.231 & 0.219 & 0.051 \\
$\mathrm{G}_{2}$ & 0.201 & 0.219 & 0.044 \\
$\mathrm{G}_{3}$ & 0.193 & 0.219 & 0.042 \\
$\mathrm{G}_{4}$ & 0.161 & 0.219 & 0.035 \\
$\mathrm{G}_{5}$ & 0.119 & 0.219 & 0.026 \\
$\mathrm{G}_{6}$ & 0.104 & 0.219 & 0.023 \\
\hline $\mathrm{D}_{2}$ & $W_{\text {Group(local })}$ & $W_{\text {Dimension }}$ & $W_{\text {Group(global) }}$ \\
\hline $\mathrm{G}_{7}$ & 0.343 & 0.781 & 0.268 \\
$\mathrm{G}_{8}$ & 0.483 & 0.781 & 0.268 \\
$\mathrm{G}_{9}$ & 0.174 & 0.781 & 0.136 \\
\hline
\end{tabular}

Table 5. Pair-wise comparison matrix and weights for each criterion

\begin{tabular}{ccccc}
\hline Demographic & $\mathrm{C}_{1}$ & $\mathrm{C}_{2}$ & $\mathrm{C}_{3}$ & $W_{\text {criteria(local) }}$ \\
\hline $\mathrm{C}_{1}$ & 1 & 0.543 & 0.655 & 0.228 \\
$\mathrm{C}_{2}$ & 1.842 & 1 & 1.447 & 0.445 \\
$\mathrm{C}_{3}$ & 1.527 & 0.691 & 1 & 0.327 \\
\hline Technological & $\mathrm{C}_{4}$ & $\mathrm{C}_{5}$ & $\mathrm{C}_{6}$ & $W_{\text {criteria(local) }}$ \\
\hline $\mathrm{C}_{4}$ & 1 & 0.923 & 0.944 & 0.316 \\
$\mathrm{C}_{5}$ & 1.084 & 1 & 0.653 & 0.295 \\
$\mathrm{C}_{6}$ & 1.059 & 1.532 & 1 & 0.389 \\
\hline Political & $\mathrm{C}_{7}$ & $\mathrm{C}_{8}$ & $\mathrm{C}_{9}$ & $W_{\text {criteria(local) }}$ \\
\hline $\mathrm{C}_{7}$ & 1 & 0.417 & 0.514 & 0.189 \\
$\mathrm{C}_{8}$ & 2.400 & 1 & 0.687 & 0.370 \\
$\mathrm{C}_{9}$ & 1.944 & 1.456 & 1 & 0.442 \\
\hline Economic & $\mathrm{C}_{10}$ & $\mathrm{C}_{11}$ & $\mathrm{C}_{12}$ & $W_{\text {criteria(local) }}$ \\
\hline $\mathrm{C}_{10}$ & 1 & 0.658 & 0.885 & 0.276 \\
$\mathrm{C}_{11}$ & 1.521 & 1 & 0.885 & 0.365 \\
$\mathrm{C}_{12}$ & 1.130 & 1.130 & 1 & 0.359 \\
\hline Socio cultural & $\mathrm{C}_{13}$ & $\mathrm{C}_{14}$ & $\mathrm{C}_{15}$ & $W_{\text {criteria(local) }}$ \\
\hline $\mathrm{C}_{13}$ & 1 & 1.565 & 1.132 & 0.398 \\
$\mathrm{C}_{14}$ & 0.639 & 1 & 0.880 & 0.272 \\
$\mathrm{C}_{15}$ & 0.883 & 1.136 & 1 & 0.330 \\
\hline
\end{tabular}


End of Table 5

\begin{tabular}{ccccccc}
\hline Industry & $\mathrm{C}_{16}$ & $\mathrm{C}_{17}$ & $\mathrm{C}_{18}$ & $\mathrm{C}_{19}$ & $\mathrm{C}_{20}$ & $W_{\text {criteria(local) }}$ \\
\hline $\mathrm{C}_{16}$ & 1 & 0.926 & 0.880 & 0.738 & 0.529 & 0.154 \\
$\mathrm{C}_{17}$ & 1.080 & 1 & 1.164 & 0.540 & 0.497 & 0.156 \\
$\mathrm{C}_{18}$ & 1.136 & 0.859 & 1 & 0.747 & 0.683 & 0.168 \\
$\mathrm{C}_{19}$ & 1.355 & 1.853 & 1.338 & 1 & 1.403 & 0.265 \\
$\mathrm{C}_{20}$ & 1.889 & 2.013 & 1.465 & 0.713 & 1 & 0.256 \\
\hline Relationship & $\mathrm{C}_{21}$ & $\mathrm{C}_{22}$ & $\mathrm{C}_{23}$ & $\mathrm{C}_{24}$ & $\mathrm{C}_{25}$ & $W_{\text {criteria(local) }}$ \\
\hline $\mathrm{C}_{21}$ & 1 & 1.059 & 2.359 & 2.374 & 1.403 & 0.284 \\
$\mathrm{C}_{22}$ & 0.944 & 1 & 2.568 & 2.430 & 1.169 & 0.275 \\
$\mathrm{C}_{23}$ & 0.424 & 0.389 & 1 & 1.423 & 0.822 & 0.136 \\
$\mathrm{C}_{24}$ & 0.421 & 0.412 & 0.703 & 1 & 0.624 & 0.112 \\
$\mathrm{C}_{25}$ & 0.713 & 0.855 & 1.217 & 1.602 & 1 & 0.194 \\
\hline $\mathrm{Tactic}$ & $\mathrm{C}_{26}$ & $\mathrm{C}_{27}$ & $\mathrm{C}_{28}$ & $\mathrm{C}_{29}$ & $\mathrm{C}_{30}$ & $W_{\text {criteria(local) }}$ \\
\hline $\mathrm{C}_{26}$ & 1.000 & 0.802 & 0.535 & 0.905 & 0.847 & 0.156 \\
$\mathrm{C}_{27}$ & 1.246 & 1.000 & 0.907 & 1.454 & 1.888 & 0.243 \\
$\mathrm{C}_{28}$ & 1.869 & 1.103 & 1.000 & 1.401 & 1.736 & 0.266 \\
$\mathrm{C}_{29}$ & 1.105 & 0.688 & 0.714 & 1.000 & 1.787 & 0.193 \\
$\mathrm{C}_{30}$ & 1.181 & 0.530 & 0.576 & 0.560 & 1.000 & 0.142 \\
\hline Specificity & $\mathrm{C}_{31}$ & $\mathrm{C}_{32}$ & & & & $W_{\text {criteria(local) }}$ \\
\hline $\mathrm{C}_{31}$ & 1 & 1.097 & & & & 0.523 \\
$\mathrm{C}_{32}$ & 0.912 & 1 & & & & 0.477 \\
\hline & & & & & &
\end{tabular}

Table 6. The relative importance weights for criteria under the Demographic Group

\begin{tabular}{cccc}
\hline Demographic & $\mathrm{C}_{1}$ & $\mathrm{C}_{2}$ & $\mathrm{C}_{3}$ \\
\hline $\mathrm{C}_{1}$ & 1 & 0.352 & 0.252 \\
$\mathrm{C}_{2}$ & 0.000 & 1 & 0.448 \\
$\mathrm{C}_{3}$ & 0.000 & 0.000 & 1 \\
\hline
\end{tabular}

Table 8. The weight matrix of inner dependence for criteria the under Economic Group

\begin{tabular}{cccc}
\hline Economic & $\mathrm{C}_{10}$ & $\mathrm{C}_{11}$ & $\mathrm{C}_{12}$ \\
\hline $\mathrm{C}_{10}$ & 1 & 0.22 & 0.00 \\
$\mathrm{C}_{11}$ & 0.00 & 0.401 & 0.446 \\
$\mathrm{C}_{12}$ & 0.00 & 0.38 & 0.55 \\
\hline
\end{tabular}

Table 7. The relative importance weights for criteria under the Technological Group

\begin{tabular}{cccc}
\hline Technological & $\mathrm{C}_{4}$ & $\mathrm{C}_{5}$ & $\mathrm{C}_{6}$ \\
\hline $\mathrm{C}_{4}$ & 0.371 & 0.382 & 0.240 \\
$\mathrm{C}_{5}$ & 0.00 & 0.62 & 0.407 \\
$\mathrm{C}_{6}$ & 0.629 & 0.00 & 0.353 \\
\hline
\end{tabular}

Table 9. The relative importance weights for criteria under the Socio Cultural Group

\begin{tabular}{cccc}
\hline Socio cultural & $\mathrm{C}_{13}$ & $\mathrm{C}_{14}$ & $\mathrm{C}_{15}$ \\
\hline $\mathrm{C}_{13}$ & 0.565 & 0.602 & 0.470 \\
$\mathrm{C}_{14}$ & 0.43 & 0.40 & 0.336 \\
$\mathrm{C}_{15}$ & 0.00 & 0.00 & 0.195 \\
\hline
\end{tabular}


Table 10. The relative importance weights for criteria under the Industry Group

\begin{tabular}{cccccc}
\hline Industry & $\mathrm{C}_{16}$ & $\mathrm{C}_{17}$ & $\mathrm{C}_{18}$ & $\mathrm{C}_{19}$ & $\mathrm{C}_{20}$ \\
\hline $\mathrm{C}_{16}$ & 1.000 & 0.000 & 0.000 & 0.239 & 0.166 \\
$\mathrm{C}_{17}$ & 0.000 & 1.000 & 0.000 & 0.000 & 0.174 \\
$\mathrm{C}_{18}$ & 0.000 & 0.000 & 0.194 & 0.159 & 0.000 \\
$\mathrm{C}_{19}$ & 0.000 & 0.000 & 0.408 & 0.367 & 0.376 \\
$\mathrm{C}_{20}$ & 0.000 & 0.000 & 0.398 & 0.235 & 0.284 \\
\hline
\end{tabular}

Table 11. The relative importance weights for criteria under the Relationship Group

\begin{tabular}{cccccc}
\hline Relationship & $\mathrm{C}_{21}$ & $\mathrm{C}_{22}$ & $\mathrm{C}_{23}$ & $\mathrm{C}_{24}$ & $\mathrm{C}_{25}$ \\
\hline $\mathrm{C}_{21}$ & 1.000 & 0.000 & 0.000 & 0.000 & 0.000 \\
$\mathrm{C}_{22}$ & 0.000 & 1.000 & 0.740 & 0.677 & 0.516 \\
$\mathrm{C}_{23}$ & 0.000 & 0.000 & 0.260 & 0.000 & 0.000 \\
$\mathrm{C}_{24}$ & 0.000 & 0.000 & 0.000 & 0.323 & 0.000 \\
$\mathrm{C}_{25}$ & 0.000 & 0.000 & 0.000 & 0.000 & 0.484 \\
\hline
\end{tabular}

Table 12. The relative importance weights for criteria under the Tactic Group

\begin{tabular}{cccccc}
\hline Tactic & $\mathrm{C}_{26}$ & $\mathrm{C}_{27}$ & $\mathrm{C}_{28}$ & $\mathrm{C}_{29}$ & $\mathrm{C}_{30}$ \\
\hline $\mathrm{C}_{26}$ & 0.289 & 0.000 & 0.000 & 0.000 & 0.000 \\
$\mathrm{C}_{27}$ & 0.000 & 0.259 & 0.290 & 0.000 & 0.000 \\
$\mathrm{C}_{28}$ & 0.000 & 0.350 & 0.318 & 0.000 & 0.000 \\
$\mathrm{C}_{29}$ & 0.361 & 0.204 & 0.201 & 1.000 & 0.531 \\
$\mathrm{C}_{30}$ & 0.350 & 0.187 & 0.191 & 0.000 & 0.469 \\
\hline
\end{tabular}

Table 13. The relative importance weights for criteria under the Specificity Group

\begin{tabular}{ccc}
\hline Specificity & $\mathrm{C}_{31}$ & $\mathrm{C}_{32}$ \\
\hline $\mathrm{C}_{31}$ & 0.473 & 0.000 \\
$\mathrm{C}_{32}$ & 0.527 & 1.000 \\
\hline
\end{tabular}

Then, criteria's interdependent weights in each assessment group are formed by multiplying dependence matrix of the criteria with the local weights of criteria.

Take the interdependent weights for $\mathrm{C}_{1}-\mathrm{C}_{3}$ under the demographic group as an example, the equation of which is as follows:

$$
w_{\mathrm{C}_{1}-\mathrm{C}_{3} \text { (interdependent) }}=\left[\begin{array}{lll}
1.000 & 0.352 & 0.252 \\
0.000 & 0.648 & 0.448 \\
0.000 & 0.000 & 0.300
\end{array}\right]\left[\begin{array}{l}
0.228 \\
0.445 \\
0.327
\end{array}\right]=\left[\begin{array}{l}
0.467 \\
0.435 \\
0.099
\end{array}\right] \text {. }
$$


Finally, multiplying the interdependent weight of each criterion with the corresponding global weight of the assessment group as shown in Table 4, the last column in Table 13 yields the computed results for all criteria. There are three categories of data in external dimension concerning ranked importance: Population number (size) $\left(\mathrm{C}_{1}\right)$, Income $\left(\mathrm{C}_{2}\right)$ and Health care and medical insurance system $\left(\mathrm{C}_{9}\right)$. The three most important criteria in core competency dimension affecting competitive-strategy selection of FDI to China are Collaboration with local partners $\left(\mathrm{C}_{22}\right)$, possession of high-quality research personnel with R\&D capability $\left(\mathrm{C}_{29}\right)$, and strong brand $\left(\mathrm{C}_{32}\right)\left(W_{\text {Criteria(global) }}=W_{\text {Criteria(interdepend- }}\right.$ ence) $\left.\times W_{\text {Criteria(local) }} \times W_{\text {Group(global) }}=W_{4} \times W_{3} \times\left(W_{1} \times W_{2}\right)\right)$.

\subsection{Determining the weights of competitive strategies with respect to each criterion}

After obtaining the global weights for criteria, it is necessary to compare the competitive strategy alternatives with respect to each criterion. Table 14 presents the weights of the alternatives under each criterion (Calculate $W_{\text {Alternative }}=W_{5}$ ).

Table 14. The computed results for all criteria

\begin{tabular}{ccccc}
\hline Group & $W_{\text {Group(global })}$ & Criteria & $W_{\text {Criteria(interdependent) }}$ & $W_{\text {Criteria(global) }}$ \\
\hline $\mathrm{G}_{1}$ & 0.051 & $\mathrm{C}_{1}$ & 0.4666 & 0.0236 \\
& & $\mathrm{C}_{2}$ & 0.4352 & 0.0220 \\
& & $\mathrm{C}_{3}$ & 0.0982 & 0.0050 \\
\hline $\mathrm{G}_{2}$ & 0.044 & $\mathrm{C}_{4}$ & 0.3232 & 0.0142 \\
& & $\mathrm{C}_{5}$ & 0.3405 & 0.0150 \\
& & $\mathrm{C}_{6}$ & 0.3362 & 0.0148 \\
\hline $\mathrm{G}_{3}$ & 0.042 & $\mathrm{C}_{7}$ & 0.1886 & 0.0080 \\
& & $\mathrm{C}_{8}$ & 0.3697 & 0.0156 \\
& & $\mathrm{C}_{9}$ & 0.4416 & 0.0187 \\
\hline $\mathrm{G}_{4}$ & 0.035 & $\mathrm{C}_{10}$ & 0.3554 & 0.0125 \\
& & $\mathrm{C}_{11}$ & 0.3061 & 0.0108 \\
& & $\mathrm{C}_{12}$ & 0.3385 & 0.0119 \\
\hline $\mathrm{G}_{5}$ & 0.026 & $\mathrm{C}_{13}$ & 0.5437 & 0.0142 \\
& & $\mathrm{C}_{14}$ & 0.3921 & 0.0102 \\
& & $\mathrm{C}_{15}$ & 0.0642 & 0.0017 \\
\hline $\mathrm{G}_{6}$ & 0.023 & $\mathrm{C}_{16}$ & 0.2600 & 0.0059 \\
& & $\mathrm{C}_{17}$ & 0.2009 & 0.0046 \\
& & $\mathrm{C}_{18}$ & 0.0748 & 0.0017 \\
& & $\mathrm{C}_{19}$ & 0.2622 & 0.0060 \\
& & $\mathrm{C}_{20}$ & 0.2021 & 0.0046 \\
\hline & & &
\end{tabular}


End of Table 14

\begin{tabular}{ccccc}
\hline Group & $W_{\text {Group(global })}$ & Criteria & $W_{\text {Criteria(interdependent })}$ & $W_{\text {Criteria(global) }}$ \\
\hline $\mathrm{G}_{7}$ & 0.268 & $\mathrm{C}_{21}$ & 0.2839 & 0.0762 \\
& & $\mathrm{C}_{22}$ & 0.5509 & 0.1478 \\
& $\mathrm{C}_{23}$ & 0.0352 & 0.0094 \\
& $\mathrm{C}_{24}$ & 0.0361 & 0.0097 \\
& & $\mathrm{C}_{25}$ & 0.0939 & 0.0252 \\
\hline $\mathrm{G}_{8}$ & 0.268 & $\mathrm{C}_{26}$ & 0.0451 & 0.0170 \\
& & $\mathrm{C}_{27}$ & 0.1401 & 0.0528 \\
& & $\mathrm{C}_{28}$ & 0.1696 & 0.0640 \\
& & $\mathrm{C}_{29}$ & 0.4277 & 0.1612 \\
& & $\mathrm{C}_{30}$ & 0.2174 & 0.0820 \\
\hline $\mathrm{G}_{9}$ & 0.136 & $\mathrm{C}_{31}$ & 0.2474 & 0.0336 \\
& & $\mathrm{C}_{32}$ & 0.7526 & 0.1022 \\
\hline
\end{tabular}

\subsection{Determining the overall priorities of the alternative strategies and obtaining the best "competitive strategy" alternative}

In this step, the final weights of "competitive strategy" alternatives are calculated. By multiplying the global weight of each criterion with the values in Table 15, we obtain the priorities for the competitive strategies (Table 16). Differentiation strategy is the best competitive strategy with a 0.3724 value. Market-focus strategy is the second best, and the remaining ranking of the alternatives is innovative-focus strategy. Take $W_{\mathrm{C} 1-\mathrm{C} 3}$ under the demographic group as an example (calculate $W_{\text {Alternative(global) }}=W_{5} \times W_{\text {Criteria(global) }}$ ).

$$
W_{\mathrm{C}_{1}-\mathrm{C}_{3}}=\left[\begin{array}{lll}
0.2740 & 0.3944 & 0.2998 \\
0.4032 & 0.3010 & 0.3015 \\
0.3229 & 0.3010 & 0.3986
\end{array}\right]\left[\begin{array}{l}
0.3026 \\
0.0220 \\
0.0050
\end{array}\right]=\left[\begin{array}{l}
0.0166 \\
0.0176 \\
0.0162
\end{array}\right] .
$$

\section{Discussion}

This study presents an effort to select the most suitable competitive strategy for multinational biotech pharmaceutical enterprises. The obtained results reveal that differentiation strategy comes in at the top of the rankings.

There are three types of medicinal drugs in China. One is brand-name drugs, which rely on their trade-based reputation and which hold patents on the drugs (the drugs can be produced and sold only by the company holding the patent). The second is off-patent drugs, which are produced by a brand-name company after the patents' expiration. The third is generic drugs, which are former brand-name drugs that, owing to the expiration of their patent and to government approval, appear on the market as generic drugs sold by non-"brand name" companies. 
Table 15. The weights of the alternatives under each criterion

\begin{tabular}{|c|c|c|c|}
\hline \multirow{2}{*}{ Criteria } & \multicolumn{3}{|c|}{ Alternatives } \\
\hline & $\mathrm{A}_{1}$ & $\mathrm{~A}_{2}$ & $\mathrm{~A}_{3}$ \\
\hline $\mathrm{C}_{1}$ & 0.274 & 0.403 & 0.323 \\
\hline $\mathrm{C}_{2}$ & 0.394 & 0.301 & 0.301 \\
\hline $\mathrm{C}_{3}$ & 0.300 & 0.302 & 0.399 \\
\hline $\mathrm{C}_{4}$ & 0.246 & 0.347 & 0.407 \\
\hline $\mathrm{C}_{5}$ & 0.213 & 0.500 & 0.287 \\
\hline $\mathrm{C}_{6}$ & 0.210 & 0.495 & 0.296 \\
\hline $\mathrm{C}_{7}$ & 0.252 & 0.395 & 0.354 \\
\hline $\mathrm{C}_{8}$ & 0.285 & 0.469 & 0.246 \\
\hline $\mathrm{C}_{9}$ & 0.329 & 0.341 & 0.330 \\
\hline $\mathrm{C}_{10}$ & 0.290 & 0.391 & 0.319 \\
\hline $\mathrm{C}_{11}$ & 0.348 & 0.349 & 0.303 \\
\hline $\mathrm{C}_{12}$ & 0.411 & 0.281 & 0.308 \\
\hline $\mathrm{C}_{13}$ & 0.428 & 0.245 & 0.326 \\
\hline $\mathrm{C}_{14}$ & 0.347 & 0.277 & 0.376 \\
\hline $\mathrm{C}_{15}$ & 0.431 & 0.264 & 0.304 \\
\hline $\mathrm{C}_{16}$ & 0.225 & 0.496 & 0.279 \\
\hline $\mathrm{C}_{17}$ & 0.316 & 0.379 & 0.305 \\
\hline $\mathrm{C}_{18}$ & 0.375 & 0.364 & 0.261 \\
\hline $\mathrm{C}_{19}$ & 0.305 & 0.399 & 0.296 \\
\hline $\mathrm{C}_{20}$ & 0.346 & 0.475 & 0.179 \\
\hline $\mathrm{C}_{21}$ & 0.319 & 0.453 & 0.228 \\
\hline $\mathrm{C}_{22}$ & 0.379 & 0.248 & 0.373 \\
\hline $\mathrm{C}_{23}$ & 0.349 & 0.350 & 0.301 \\
\hline $\mathrm{C}_{24}$ & 0.423 & 0.334 & 0.243 \\
\hline $\mathrm{C}_{25}$ & 0.476 & 0.240 & 0.283 \\
\hline $\mathrm{C}_{26}$ & 0.196 & 0.414 & 0.390 \\
\hline $\mathrm{C}_{27}$ & 0.452 & 0.178 & 0.370 \\
\hline $\mathrm{C}_{28}$ & 0.479 & 0.229 & 0.292 \\
\hline $\mathrm{C}_{29}$ & 0.357 & 0.300 & 0.342 \\
\hline $\mathrm{C}_{30}$ & 0.385 & 0.291 & 0.324 \\
\hline $\mathrm{C}_{31}$ & 0.412 & 0.358 & 0.230 \\
\hline $\mathrm{C}_{32}$ & 0.425 & 0.315 & 0.260 \\
\hline
\end{tabular}


Table 16. Results of competitive strategy alternatives

\begin{tabular}{cccc}
\hline \multirow{2}{*}{ Group } & \multicolumn{3}{c}{ Alternatives } \\
\cline { 2 - 4 } & $\mathrm{A}_{1}$ & $\mathrm{~A}_{2}$ & $\mathrm{~A}_{3}$ \\
\hline $\mathrm{G}_{1}$ & 0.0166 & 0.0176 & 0.0162 \\
$\mathrm{G}_{2}$ & 0.0097 & 0.0191 & 0.0152 \\
$\mathrm{G}_{3}$ & 0.0126 & 0.0168 & 0.0128 \\
$\mathrm{G}_{4}$ & 0.0123 & 0.0120 & 0.0109 \\
$\mathrm{G}_{5}$ & 0.0103 & 0.0067 & 0.0090 \\
$\mathrm{G}_{6}$ & 0.0068 & 0.0099 & 0.0061 \\
$\mathrm{G}_{7}$ & 0.0997 & 0.0838 & 0.0847 \\
$\mathrm{G}_{8}$ & 0.1470 & 0.1034 & 0.1266 \\
$\mathrm{G}_{9}$ & 0.0572 & 0.0442 & 0.0343 \\
$\mathrm{Sum}$ & 0.3724 & 0.3136 & 0.3159 \\
\hline
\end{tabular}

Because most China-based biotech pharmaceutical firms are small and medium-size enterprises (SMEs), it is difficult to invest significant sums of money in new-drug innovation, particularly given the risk of disappointing results stemming from long-term drug-development research. Both foreign and joint-venture pharmaceutical firms in China have a monopoly in the brand-name drugs market and the off-patent drugs market. Multinational biotech pharmaceutical enterprises should adopt differentiation strategy rather than a simple strategy of new-product development in order (1) to avoid harmful competition with other MNEs in the brand-name drug market, (2) to shorten time-consuming and complex approval processes for new drugs from the State Food and Drug Administration (SFDA), (3) to reduce the risk of incurring fruitless and unnecessarily expensive research and development costs, and (4) to avoid avoidable declines in profit due to insufficient protection under intellectual property rights law.

For example, first, multinational biotech pharmaceutical enterprises could focus on the development of new formulations, new delivery systems, new indications, or new combinations of new drugs, not just the development of new entities. Moreover, multinational biotech pharmaceutical enterprises could enter the market by focusing on the specific diseases or ailments to which people in China are vulnerable (e.g., hepatitis B, oral cancer, diabetes mellitus, asthma, and nasopharyngeal cancer). Third, multinational biotech pharmaceutical enterprises could input more resources in the generic-drug market to increase profits since the market size is projected to reach more than US $\$ 88.5$ from 2010 to 2014.

Segment size and potential growth are requirements for effective international segmentation. Since the EU and US economies have slowed, the pharmaceutical and biotech industries have demonstrated tremendous growth potential in emerging markets. Among all emerging economies, the focus is more on China than on any other territory owing 
to rising demand in China's massive population and particularly in its rapidly growing middle class. China's pharmaceutical market will continue to grow more at approximately $20 \%$ annually, and will account for approximately $21 \%$ of overall global growth through 2013. And by 2020, the value of China's total pharmaceutical market is projected to be US\$120 billion; indeed, China is predicted to overtake the United States in becoming the world's largest, and China's biotech market is expected to grow strongly as well. Biotech revenue growth in China alone is projected to exceed 25 percent within the next five years. Pharmaceutical sales are growing at a fast rate in China owing to the growth of Chinese per capita income that gives people more disposable income to spend on medicine. Furthermore, the continuous reorientation of healthcare and medical insurance systems toward business and market issues has caused China's biotech pharmaceutical industry to acquire a huge space in which to develop. Hence, from an external environment analysis, the current study's weighted calculations strongly suggest that the three most important criteria affecting competitive-strategy selection of FDI to China are population size $\left(\mathrm{C}_{1}\right)$, per capita income $\left(\mathrm{C}_{2}\right)$, and healthcare and medical insurance systems $\left(\mathrm{C}_{9}\right)$.

Drug development is extremely time-consuming and costly. No single organization has all the expertise necessary to produce the medical innovations that customers want. Therefore, MNCs that collaborate with useful entities on the domestic front (i.e., that form strategic alliances with complementing resources in the host country) will gain access to new research capabilities, accelerate products' introduction time (thereby granting first-mover advantage to the MNCs), and reduce the risk of incurring fruitless and unnecessarily expensive research and development costs. To progress beyond incremental improvements, biotech pharmaceutical firms should not only continuously cultivate internal expertise but also collaborate with partners whose capabilities augment its own. Such collaborations enable a biotech pharmaceutical firm to strengthen its entire R\&D value chain (Kak 2004). Furthermore, MNCs' cooperation with local partners can accelerate the MNCs' entrance into the Chinese market, thereby enabling the MNCs to overcome obstacles related to cultural, language, geographical, and political barriers. The biotech pharmaceutical industry is a knowledge-intensive industry so that the availability of high-quality research personnel proficient in R\&D activities has became an important factor. Drug innovation is also a necessity for multinational biotech pharmaceutical enterprises' successful international competition. Biotech pharmaceutical enterprises seeking to undertake research and product-development activities should adopt strategies that result in the realization of optimum innovation levels and optimum returns on investment in pursuit of these goals. People with R\&D capability are central to non-Chinese multinational biotech pharmaceutical companies seeking to enter China in ways that enable the companies to market innovative products, to improve operational performance, and to gain competitive advantage over rivals. A review of the Chinese pharmaceutical market reveals that the domestic pharmaceutical market is highly fragmented and inefficient. Biotech pharmaceutical enterprises have understood that they operate in a low-trust environment and have hoped that a strong brand image can strategically increase their own share of the market. Creating a strong brand 
image and building brand awareness is especially critical to China's pharmaceutical enterprises as they look to win consumers' trust in the quality, safety, and effectiveness of their products. Once enterprises develop a good brand image, they can use it as a tool to open further opportunities, to expand their targeted market, and to acquire a larger share of the expanded market. The goals of the Phi conference in 2011 are to enhance brand awareness, to develop business relationships, and to launch new products; hence, the current study's weighted calculations strongly suggest that, from a core competency analysis, the three most important criteria affecting competitive-strategy selection of FDI to China are capability in collaborating with local partners $\left(\mathrm{C}_{22}\right)$, possession of high-quality research personnel with $\mathrm{R} \& \mathrm{D}$ capability $\left(\mathrm{C}_{29}\right)$, and strong brand $\left(\mathrm{C}_{32}\right)$.

\section{Conclusions}

In this study, we have sought to identify the most appropriate competitive strategy for multinational biotech pharmaceutical enterprises that plan to invest, or have already invested, in China. By harnessing an ANP technique that combines both qualitative and quantitative information, we proposed a hierarchical model for competitive-strategy selection. The model consists of 1 goal, 2 assessment dimensions, 9 groups, 32 criteria, and 3 alternatives. With the help of interactions between criteria under each group, the data reflects the reality in a better way. This study's use of ANP has revealed that the most suitable competitive strategy for MNEs is differentiation strategy, followed by market-focus strategy and innovative focus (in the order of descending importance). The results of this study have also revealed two other significant points: external environment analysis has revealed that the three most important criteria affecting the competitive strategy selection of FDI to China are population size $\left(C_{1}\right)$, per capita income $\left(C_{2}\right)$, and healthcare and medical insurance systems $\left(\mathrm{C}_{9}\right)$; and core competency analysis has revealed that the three most important criteria affecting competitive-strategy selection of FDI to China are capability in collaborating with local partners $\left(\mathrm{C}_{22}\right)$, possession of high-quality research personnel with R\&D capability $\left(\mathrm{C}_{29}\right)$, and strong brand $\left(\mathrm{C}_{32}\right)$.

Future studies can incorporate more important criteria and competitive strategies to expand and refine the model. In addition, future studies can use this model to research strategy selection as it applies to product categories' fitness for foreign investment.

\section{Acknowledgement}

The authors are grateful to the editor and the three anonymous referees for their insightful comments and suggestions. This work was supported by the Tamkang University of Taiwan and the National Science Council of Taiwan under Grants NSC 96-2119-M130-001. 


\section{References}

Allen, R. S.; Helms, M.; Takeda, M.; White, C. S. 1999. A comparison of competitive strategies in Japan and the United, SAM Advanced Management Journal 71(1): 24-34.

Barczak, G. 1995. New product strategy, structure, process, and performance in the telecommunications industry, Journal of Product Innovation Management 12(3): 224-234.

http://dx.doi.org/10.1111/1540-5885.1230224

Bernard, J. 2010. What Is Strategy [retrieved 25 January 2011]. Available from Internet: http:// www. ecofine. com/strategy/strategy.htm

Bevilacqua, M.; D’Amore, A.; Polonara, F. 2004. A multi-criteria decision approach to choosing the optimal blanching-freezing system, Journal of Food Engineering 63: 253-263.

http://dx.doi.org/10.1016/j.jfoodeng.2003.07.007

Bogner, W. C.; Thomas, H.; McGee, J. 1996. A longitudinal study of the competitive positions and entry paths of European firms in the US pharmaceutical industry, Strategic Management Journal 17(2): 85-109.

http://dx.doi.org/10.1002/(SICI)1097-0266(199602)17:2<85::AID-SMJ785>3.0.CO;2-D

Brandenburger, A.; Stuart, H. 1996. Value-based business strategy, Journal of Economics \& Management Strategy 5: 5-24. http://dx.doi.org/10.1111/j.1430-9134.1996.00005.x

Brouthers, K. D. 2002. Institutional, cultural and transaction cost influences on entry mode choice and performance, Journal of International Business Studies 33(2): 203-221.

http://dx.doi.org/10.1057/palgrave.jibs.8491013

Business Wire. 2009. China's Biopharmaceutical Industry Report [retrieved 20 November 2010]. Available from Internet: http://www.businesswire.com/portal/site/home

Chen, L. M.; Lou, S. H. 2004. The Strategic Alliances for Bio-tech and Pharmaceutical Company. ITIS Project of Development Center of Bio-tech in Taiwan.

Chin, K. S.; Chiu, S.; Tummala, V. M. R. 1999. An evaluation of success factors using the AHP to implement ISO 14001- based ESM, International Journal of Quality and Reliability Management 16(4): 341-361. http://dx.doi.org/10.1108/02656719910248226

China Research and Intelligent. 2008. Market Report on China's Biopharmaceutical Industry, 2008-2010 [retrieved 20 November 2010]. Available from Internet: http://prlog.org/10136857

Chrisman, J.; Hofer, C.; Bolton, W. 1988. Toward a system for classifying business strategies, Academy of Management Review 13(3): 413-428.

Chung, S. H.; Lee, A. H. L.; Pearn, W. L. 2005. Analytic network process (ANP) approach for product mix planning in semiconductor fabricator, International Journal of Production Economics 96: 15-36. http://dx.doi.org/10.1016/j.ijpe.2004.02.006

De Saa-Perez, P.; Garcia-Falcon, J. M. 2002. A resource-based view of human resource management and organizational capabilities development, International Journal Human Resource 13: 123-140. http://dx.doi.org/10.1080/09585190110092848

Deeds, D. L.; Hill, C. W. L. 1996. Strategic alliances and the rate of new product development: an empirical study of entrepreneurial biotechnology firms, Journal of Business Venturing 11(1): 41-55. http://dx.doi.org/10.1016/0883-9026(95)00087-9

Expert Choice, Analytical Hierarchy Process (AHP) Software. 2000. Version 9.5. Pittsburg.

Feltz, T. V. D. 2007. Recruitment perspectives, the future of R\&D leadership, Journal of Medical Marketing 7: 265-267.

Ghazinoory, S.; Abdi, M.; Azadegan-Mehr, M. 2011. Swot methodology: a state-of-the-art review for the past: a framework for the future, Journal of Business Economics and Management 12(1): 24-48. http://dx.doi.org/10.3846/16111699.2011.555358 
Grant, R. M. 1991. The resource-based view of competitive advantage: implication for strategy formulation, California Management Journal 33: 11-134.

Ginevičius, R.; Krivka, A.; Šimkūnaite, J. 2010. The model of forming competitive strategy of an enterprise under the conditions of oligopolic market, Journal of Business Economics and Management 11(3): 367-395. http://dx.doi.org/10.3846/jbem.2010.18

Ginter, P. M.; Duncan, W. J.; Capper, S. A. 1992. Keeping strategic thinking in strategic planning: macro-environmental analysis in a state department of public health, The Society of Public Health 106: 253-269. http://dx.doi.org/10.1016/S0033-3506(05)80418-4

Hitt, M. A.; Ireland, R. D.; Hoskisson, R. E. 2007. Strategic Management: Competitiveness and Globalization. Cincinnati: Thomson South-Western.

Hoskission, R. E.; Hitt, M. A.; Ireland, R. D. 2004. Competing for Advantage. Cincinatti, Ohio: South-Western College Publishing Company.

Kak, A. 2004. Strategic management, core competencies and flexibility: learning issues for select pharmaceutical organizations, Global Journal of Flexible System Management 5(4): 1-15.

Karnitis, E.; Kucinskis, M. 2009. Strategic planning and management of national development processes in Latvia, Journal of Business Economics and Management 10(1): 3-13.

http://dx.doi.org/10.3846/1611-1699.2009.10.3-13

Kirca, A. H.; Jayachandran, S.; Bearden, W. O. 2005. Market orientated: a meta-analytic review and assessment of its antecedent and impact on performance, Journal of Marketing 69(April): 24-41. http://dx.doi.org/10.1509/jmkg.69.2.24.60761

Korsakiene, R. 2004. Determining competitive advantage: the analytic hierarchy process, Journal of Business Economics and Management 5(4): 205-215.

Lahti, R. M. 1999. Identifying and integrating individual level and organizational level core competencies, Journal of Business and Psychology 14(1): 59-75.

http://dx.doi.org/10.1023/A:1022906400927

Lee, J. W.; Kim, S. H. 2000. Using analytic network process and goal programming for interdependent information system project selection, Computers and Operations Research 27: 367-382. http://dx.doi.org/10.1016/S0305-0548(99)00057-X

Lee, J. W.; Kim, S. H. 2001. An integrated approach for independent information system project selection, International Journal of Project Management 19: 111-118.

http://dx.doi.org/10.1016/S0263-7863(99)00053-8

Lin, R. H. 2009. An integrated FANP-HOLP for supplier evaluation and order allocation, Applied Mathematical Modelling 33: 2730-2736. http://dx.doi.org/10.1016/j.apm.2008.08.021

Liu, S. S.; Cheng, M. 2000. Toward a framework for entering China's pharmaceutical market, Marketing Intelligence \& Planning 18(5): 227-235. http://dx.doi.org/10.1108/02634500010343928

Management Study Guide. 2011. Strategic management process-meaning, steps and components [retrieved 10 April 2011]. Available from Internet: http://www.managementstudyguide.com/ strategic-management-process.htm

Matsuno, K.; Mentzer, J. T. 2000. The effects of strategy type on the market orientation-performance relationship, Journal of Marketing 54: 1-16. http://dx.doi.org/10.1509/jmkg.64.4.1.18078

Meade, L. M.; Sarkis, J. 1998. Strategic analysis of logistics and supply chain management systems using the analytical network process, Transportation Research Part E: Logistics and Transportation Review 34: 201-215. http://dx.doi.org/10.1016/S1366-5545(98)00012-X

Meade, L. M.; Sarkis, J. 1999. Analyzing organizational project alternatives for agile manufacturing processes: an analytical network approach, International Journal of Production Research 37(2): 241-261. http://dx.doi.org/10.1080/002075499191751 
Mehta, S.; Peters, L. S. 2007. Outsourcing a core competency, Research Technology Management 50(3): 28-34.

Miles, R. E.; Snow, C. C. 1978. Organizational Strategy, Structure, and Process. New York, NY: McGraw-Hill.

Momoh, J. A.; Zhu, J. 2003. Optimal generation-scheduling based on AHP/ANP, IEEE Transactions on Systems, Man, and Cybernetics-Part B: Cybernetics 33: 531-535.

http://dx.doi.org/10.1109/TSMCB.2003.811122

Olson, E. M.; Slater, S. F.; Hult, G. T. M. 2005. The performance implications of fit: among business strategy, marketing organization structure and strategic behavior, Journal of Marketing 69(July): 49-65. http://dx.doi.org/10.1509/jmkg.69.3.49.66362

O'Regan, N.; Ghobadian, A. 2004. The importance of capabilities for strategic direction and performance, Management Decision 42(2): 292-312. http://dx.doi.org/10.1108/00251740410518525

Pan, H. 1999. A new product launch strategy (NPLS) model for pharmaceutical companies. Unpublished MSc dissertation. Department of Management, Birkbeck College, University of London, London.

Partovi, F. Y. 2006. An analytic model for locating facilities strategically, Omega 34(1): 41-55. http://dx.doi.org/10.1016/j.omega.2004.07.018

Pearce, J. A.; Robinson, R. B. 2003. Strategic Management: Strategy Formulation, Implementation and Control. 8th ed. Chicago, IL: R.D. Irwin, Inc.

Porter, M. E. 1980. Competitive Strategy. New York, NY: Free Press.

Powell, W. W.; Brantley, P. 1992. Competitive cooperation in biotechnology: learning through networks, in Nohria, N.; Eccles, R. (Eds.). Network and Organizations: Structure, Form and Action. MA: Harvard Business School Press.

Prahalad, C. K.; Hamel, G. 1990. The core competence of the corporation, Harvard Business Review 68(3): 79-91.

Richards, M.; DeCarolis, D. M. 2003. Joint venture research and development activity: an analysis of the international biotechnology industry, Journal of International Management 9: 33-49. http://dx.doi.org/10.1016/S1075-4253(03)00002-4

Saaty, T. L. 1980. The Analytic Hierarchy Process. New York, NY: McGraw-Hill.

Saaty, T. L. 1996. Decision making with dependence and feedback: the analytic network process. Pittsburgh, PA: RWS Publications.

Saaty, T. L. 2005. Theory and Applications of the Analytic Network Process: Decision Making with Benefits, Opportunities, Costs, and Risks. Pittsburgh, PA: RWS Publications.

Saaty, T. L. 2006. Rank from comparisons and from ratings in the analytic hierarchy/network processes, European Journal of Operational Research 168: 557-570.

Sarkis, J. 2002. A model for strategic supplier selection, Journal of Supply Chain Management 38: 18-28. http://dx.doi.org/10.1016/j.ejor.2004.04.032

Shan, W.; Song, J. 1997. Foreign direct investment and the sourcing of technological advantage: evidence from the biotechnology industry, Journal of International Business Studies 28(2): 267-284. http://dx.doi.org/10.1057/palgrave.jibs.8490101

Spanos, Y. E.; Lioukas, S. 2001. An examination into the causal logic of performance effects of knowledge management with information technology: roles of dynamic capability, competitive strategy, and strategic fit rent generation: contrasting porter's competitive strategy framework and the resource-based perspective, Strategic Management Journal 22: 907-934.

http://dx.doi.org/10.1002/smj.174

Stevenson, W. 1996. Production Operations Management. 5th ed. Chicago: Irwin Publishing Company. 
Strandskov, J. 2006. Sources of competitive advantages and business performance, Journal of Business Economics and Management 7(3): 119-129.

Swamidass, P. M.; Newell, W. T. 1987. Manufacturing strategy, environmental uncertainty and performance: a path analytic model, Management Science 33(4): 509-524.

http://dx.doi.org/10.1287/mnsc.33.4.509

Tesfamariam, D.; Lindberg, B. 2005. Aggregate analysis of manufacturing systems using system dynamics and ANP, Computers \& Industrial Engineering 49: 98-117.

http://dx.doi.org/10.1016/j.cie.2005.05.001

Thenmozhi, M. 2011. Management science I: MODULE 9-9.1. Strategy formulation: an overview, in Indian Institute of Technology Madras, 1-48.

Toni, A. D.; Tonchia, S. 2003. Strategic planning and firm's competencies: traditional approaches and new perspectives, International Journal of Operations \& Production Management 23(9): 947-976. http://dx.doi.org/10.1108/01443570310491729

Trim, P.; Pan, H. 2005. A new product launch strategy (NPLS) model for pharmaceutical companies, European Business Review 17(4): 325-339. http://dx.doi.org/10.1108/09555340510607370

Ulutas, B. H. 2005. Determination of the appropriate energy policy of Turkey, Energy 30: 11461161. http://dx.doi.org/10.1016/j.energy.2004.08.009

Volberda, H. W. 1996. Toward the flexible form: how to remain vital in hypercompetitive environments, Organization Science 7(4): 359-374. http://dx.doi.org/10.1287/orsc.7.4.359

Vorhies, D. W.; Morgan, N. A. 2003. A configuration theory assessment of marketing organization fit with business strategy and its relationship with marketing performance, Journal of Marketing 63(1): 100-115. http://dx.doi.org/10.1509/jmkg.67.1.100.18588

Wernerfelt, A. 1984. Resource-based view of the firm, Strategic Management Journal 5: 171180. http://dx.doi.org/10.1002/smj.4250050207

Wua, W. W.; Lee, Y. T. 2007. Selecting knowledge management strategies by using the analytic network process, Expert Systems with Applications 32: 841-847.

http://dx.doi.org/10.1016/j.eswa.2006.01.029

Yüksel, I.; Dagdeviren, M. 2007. Using the analytic network process (ANP) in a SWOT analysis - a case study for a textile firm, Information Sciences 177: 3364-3382.

http://dx.doi.org/10.1016/j.ins.2007.01.001

Yurdakul, M. 2003. Measuring long-term performance of a manufacturing firm using the analytical network process (ANP) approach, International Journal of Production Research 41: 2501-2529. http://dx.doi.org/10.1080/0020754031000088183

Zhou, Y. B. 2007. Pharmaceutical distribution in China: the country strives to modernize its distribution logistics as thousands of small companies compete for profits [retrieved 30 July 2011]. Available from Internet: http://www.bioplanassociates.com/publications/articles.htm 


\section{APPENDIX 1}

\section{Expert Backgrounds (FGD)}

\begin{tabular}{|c|c|c|}
\hline & Expert & Experience \& Expertise \\
\hline \multirow[t]{2}{*}{1} & Experience & $\begin{array}{l}30 \text { years of experience in a multi-national pharmaceutical company } \\
\text { in China. Currently leads the China Pharmaceutical Enterprise Association } \\
\text { (Association manager) }\end{array}$ \\
\hline & Expertise & Business development; marketing and sales \\
\hline \multirow[t]{2}{*}{2} & Experience & $\begin{array}{l}30 \text { years of experience in a multi-national pharmaceutical company } \\
\text { in China. Currently leads a management consulting company in Taiwan }\end{array}$ \\
\hline & Expertise & Business development; marketing and sales \\
\hline \multirow[t]{2}{*}{3} & Experience & $\begin{array}{l}25 \text { years of experience in a multi-national pharmaceutical company } \\
\text { in China. Currently owns a pharmaceutical trading company in China }\end{array}$ \\
\hline & Expertise & Business development; marketing and sales \\
\hline \multirow[t]{2}{*}{4} & Experience & $\begin{array}{l}25 \text { years of experience in a multi-national pharmaceutical company } \\
\text { in China. Currently is on track to become a top manager in a China-based } \\
\text { pharmaceutical MNE }\end{array}$ \\
\hline & Expertise & Business Development; Marketing and Sales \\
\hline \multirow[t]{2}{*}{5} & Experience & $\begin{array}{l}20 \text { years of experience in a multi-national pharmaceutical company } \\
\text { in China. Currently leads a pharmaceutical trading company in Taiwan }\end{array}$ \\
\hline & Expertise & Business development; marketing and sales \\
\hline \multirow[t]{2}{*}{6} & Experience & $\begin{array}{l}15 \text { years of experience in a multi-national pharmaceutical company } \\
\text { in China. Currently leads the China Pharmaceutical Enterprise Association } \\
\text { (Association Director) }\end{array}$ \\
\hline & Expertise & Marketing and sales \\
\hline \multirow[t]{2}{*}{7} & Experience & $\begin{array}{l}10 \text { years of experience in a multi-national pharmaceutical company } \\
\text { in China. Currently works in a management consulting company. }\end{array}$ \\
\hline & Expertise & Marketing and sales \\
\hline \multirow[t]{2}{*}{8} & Experience & $\begin{array}{l}10 \text { years of experience in a multi-national pharmaceutical company } \\
\text { in China. Currently is on track to become a top manager in a local } \\
\text { pharmaceutical company in China }\end{array}$ \\
\hline & Expertise & Marketing and sales \\
\hline
\end{tabular}




\section{APPENDIX 2}

\section{The definition of assessment criteria and alternatives}

\begin{tabular}{|c|c|}
\hline Criteria & Definition \\
\hline Population numbers (Size) $\left(\mathrm{C}_{1}\right)$ & $\begin{array}{l}\text { The total number of people inhabiting a specific area } \\
\text { in China }\end{array}$ \\
\hline Per capita income $\left(\mathrm{C}_{2}\right)$ & Income per person in a selected population in China \\
\hline Living standards $\left(\mathrm{C}_{3}\right)$ & $\begin{array}{l}\text { A level of material comfort as measured by the goods, } \\
\text { services, and luxuries available to an individual, group, } \\
\text { or nation }\end{array}$ \\
\hline $\begin{array}{l}\text { The current status of the biotech } \\
\text { pharmaceutical industry }\left(\mathrm{C}_{4}\right)\end{array}$ & $\begin{array}{l}\text { The current status of China's biotech pharmaceutical } \\
\text { industry }\end{array}$ \\
\hline $\begin{array}{l}\text { New pharmaceutical } \\
\text { technologies }\left(\mathrm{C}_{5}\right)\end{array}$ & $\begin{array}{l}\text { The possibility of new pharmaceutical-technologies } \\
\text { development }\end{array}$ \\
\hline $\begin{array}{l}\text { Supply of } R \& D \text { human capital } \\
\left(\mathrm{C}_{6}\right)\end{array}$ & Sufficient research-personnel supply in China \\
\hline $\begin{array}{l}\text { Government regulation of } \\
\text { investment }\left(\mathrm{C}_{7}\right)\end{array}$ & Public-sector oversight of speculation in assets \\
\hline $\begin{array}{l}\text { Government regulation of } \\
\text { product launches }\left(\mathrm{C}_{8}\right)\end{array}$ & $\begin{array}{l}\text { These include clinical-trial regulation and pricing } \\
\text { management }\end{array}$ \\
\hline $\begin{array}{l}\text { Healthcare and medical } \\
\text { insurance systems }\left(\mathrm{C}_{9}\right)\end{array}$ & Healthcare and medical insurance systems in China \\
\hline Exchange rate $\left(\mathrm{C}_{10}\right)$ & Change in the exchange rate \\
\hline GNP growth $\left(\mathrm{C}_{11}\right)$ & Per capita gross national product \\
\hline Inflation/unemployment $\left(\mathrm{C}_{12}\right)$ & Unemployment rate \\
\hline $\begin{array}{l}\text { Emergence of concepts about } \\
\text { healthcare, etc. }\left(\mathrm{C}_{13}\right)\end{array}$ & $\begin{array}{l}\text { Health-related approaches, which are becoming more } \\
\text { high-tech and which involve biotech drugs }\end{array}$ \\
\hline $\begin{array}{l}\text { Evolution of individual values } \\
\left(\mathrm{C}_{14}\right)\end{array}$ & $\begin{array}{l}\text { Heightened attention to personal standards regarding } \\
\text { health }\end{array}$ \\
\hline Consumer behavior $\left(\mathrm{C}_{15}\right)$ & $\begin{array}{l}\text { Changes in shoppers' practices (self-prescribed medicine, } \\
\text { medicine purchases, on-line aspects of medicine, modern } \\
\text { medicine) }\end{array}$ \\
\hline Barriers to entry $\left(\mathrm{C}_{16}\right)$ & $\begin{array}{l}\text { The biotech pharmaceutical industry may obstruct entry } \\
\text { through, for example, economies of scale, brand loyalty } \\
\text { of customers, and constant investment }\end{array}$ \\
\hline $\begin{array}{l}\text { Bargaining power of suppliers } \\
\left(\mathrm{C}_{17}\right)\end{array}$ & Companies' ability to keep down costs of sales \\
\hline $\begin{array}{l}\text { Bargaining power of buyers } \\
\left(\mathrm{C}_{18}\right)\end{array}$ & Customers' ability to force down prices \\
\hline $\begin{array}{l}\text { Rivalry among existing players } \\
\left(\mathrm{C}_{19}\right)\end{array}$ & $\begin{array}{l}\text { Competitors may use tactics such as price competition, } \\
\text { product introduction, and advertising campaigns }\end{array}$ \\
\hline
\end{tabular}


Continue of Appendix 2

\begin{tabular}{|c|c|}
\hline Criteria & Definition \\
\hline $\begin{array}{l}\text { Threat of substitute products } \\
\left(\mathrm{C}_{20}\right)\end{array}$ & $\begin{array}{l}\text { Substitute products exert pressure on enterprises within an } \\
\text { industry. This is done by offering an alternative product to } \\
\text { the customer }\end{array}$ \\
\hline $\begin{array}{l}\text { Capability in dealing with } \\
\text { governmental rules and } \\
\text { regulations }\left(\mathrm{C}_{21}\right)\end{array}$ & $\begin{array}{l}\text { The biotech pharmaceutical firm can deal with the host } \\
\text { country's state-mandated laws, standards, and guidelines } \\
\text { governing such matters as investment-regulation regimes, } \\
\text { patent acquisition, drug-pricing systems, public health } \\
\text { insurance, import-export controls, work and resident visas, } \\
\text { and trademark policies }\end{array}$ \\
\hline $\begin{array}{l}\text { Collaboration with local partners } \\
\left(\mathrm{C}_{22}\right)\end{array}$ & $\begin{array}{l}\text { The biotech pharmaceutical firm can work with local } \\
\text { partners in ways that gain the firm quick access to local } \\
\text { markets }\end{array}$ \\
\hline $\begin{array}{l}\text { Capability in building } \\
\text { relationships with } R \& D \text { centers } \\
\left(\mathrm{C}_{23}\right)\end{array}$ & $\begin{array}{l}\text { The biotech pharmaceutical firm can develop links with } \\
\text { research institutions in the host country to accelerate } \\
\text { products' introduction time and to reduce the risk of } \\
\text { incurring unnecessary research-and-development expenses }\end{array}$ \\
\hline $\begin{array}{l}\text { Capability in building } \\
\text { relationships with universities } \\
\left(\mathrm{C}_{24}\right)\end{array}$ & $\begin{array}{l}\text { The biotech pharmaceutical firm can develop links with } \\
\text { academic institutions for knowledge-related sharing and } \\
\text { collaboration }\end{array}$ \\
\hline $\begin{array}{l}\text { Capability in building customer } \\
\text { relationships }\left(\mathrm{C}_{25}\right)\end{array}$ & $\begin{array}{l}\text { The biotech pharmaceutical firm can develop customer } \\
\text { relationships to clarify customer needs, to develop needed } \\
\text { medicines, and to offer good sales service }\end{array}$ \\
\hline Support of funding $\left(\mathrm{C}_{26}\right)$ & $\begin{array}{l}\text { The biotech pharmaceutical firm can obtain sufficient } \\
\text { long-term financing from diverse channels, including } \\
\text { initial public offerings, venture capital, or cash flow from } \\
\text { product sales }\end{array}$ \\
\hline $\begin{array}{l}\text { Building wide channel } \\
\text { distributions }\left(\mathrm{C}_{27}\right)\end{array}$ & $\begin{array}{l}\text { The biotech pharmaceutical firm can develop diverse sites } \\
\text { for channel distribution, including such sites as hospitals, } \\
\text { clinics, pharmacies, and e-commerce establishments }\end{array}$ \\
\hline Marketing capability $\left(\mathrm{C}_{28}\right)$ & $\begin{array}{l}\text { The biotech pharmaceutical firm can conduct promotional } \\
\text { activities through advertising, public relations, and } \\
\text { personal sales to market new products, to acquire high- } \\
\text { potential pharmaceutical-product customers, and to help } \\
\text { the firm shift its orientation outward to customers and their } \\
\text { unmet medical needs }\end{array}$ \\
\hline $\begin{array}{l}\text { High-quality research personnel } \\
\text { with } R \& D \text { capability }\left(C_{29}\right)\end{array}$ & $\begin{array}{l}\text { The biotech pharmaceutical firm possesses skilled and } \\
\text { talented workers who can effectively study and create } \\
\text { novel innovative products }\end{array}$ \\
\hline $\begin{array}{l}\text { Excellent information systems } \\
\left(\mathrm{C}_{30}\right)\end{array}$ & $\begin{array}{l}\text { The biotech pharmaceutical firm possesses data-processing } \\
\text { mechanisms that strengthen the firm's platform for } \\
\text { developing a global, effective supply chain and for } \\
\text { establishing industry networks }\end{array}$ \\
\hline
\end{tabular}


End of Appendix 2

\begin{tabular}{ll}
\hline \multicolumn{1}{c}{ Criteria } & \multicolumn{1}{c}{ Definition } \\
\hline $\begin{array}{l}\text { Strategic management of } \\
\text { globalization }\left(\mathrm{C}_{31}\right)\end{array}$ & $\begin{array}{l}\text { The biotech pharmaceutical firm can effectively handle } \\
\text { international matters in pursuit of short- and long-term } \\
\text { firm goals, and can specifically familiarize itself with } \\
\text { relevant aspects of the host country (e.g., business } \\
\text { behaviors there) }\end{array}$ \\
\hline Strong brand $\left(\mathrm{C}_{32}\right)$ & $\begin{array}{l}\text { The biotech pharmaceutical firm possesses an invaluable } \\
\text { trademark reputation that makes specific promises of value } \\
\text { embedded in customers' awareness }\end{array}$ \\
\hline Differentiation strategy $\left(\mathrm{A}_{1}\right)$ & $\begin{array}{l}\text { Entering the market by focusing on specific diseases or } \\
\text { ailments to which people in China are vulnerable (e.g., } \\
\text { hepatitis B, oral cancer, diabetes mellitus, asthma, and } \\
\text { nasopharyngeal cancer) }\end{array}$ \\
\hline Market-focus strategy $\left(\mathrm{A}_{2}\right)$ & $\begin{array}{l}\text { Focusing on the higher-end market, which is composed } \\
\text { of wealthy consumers enthusiastic about health food and } \\
\text { medical cosmetology in China }\end{array}$ \\
\hline Innovative-focus strategy $\left(\mathrm{A}_{3}\right)$ & \begin{tabular}{l} 
Entering the market with a new patented drug \\
\hline
\end{tabular} \\
\hline
\end{tabular}

Yun-Huei LEE. An Assistant Professor of Business Administration at Tamkang University in Taiwan. She received her PhD in Business Management from the National Dong Hwa University in 2008. Her research interests include empirical exploration of strategic issues, more specifically focusing on international market entry strategy and new product development of technology management.

Yun-Huan LEE. An Assistant Professor of Finance Department at Ming Chuan University in Taiwan. He received the PhD in statistics from the National Central University in 2005. His research interests are the prediction of financial time series, risk evaluation, and data analysis. 